\title{
Material Crack
}

National Cancer Institute

\section{Source}

National Cancer Institute. Material Crack. NCI Thesaurus. Code C62971.

Problem associated with an undesired partial separation and/or a visible opening along the length or width in the materials that are used in the device construction. 